\title{
Desire for and Explore on World Peace
}

\author{
Yue Yang \\ Guangzhou, China \\ E-mail: yyllqq2007@163.com
}

\begin{abstract}
World peace is the social orders featured with globalization, security, harmony, and stability. At the time of globalization, everyone should face and care for this issue. This paper points out people's desire for world peace and discusses this issue from ideas, popularity, dangers, emergence, and practice.
\end{abstract}

Keywords: Globalization, World peace, World politics, International relations

In the field of international relations, world peace is always a vital subject. In the globalization forum, world peace is also the focus of attentions and an inevitable theme in research. From the political and legal point of view, world peace is the social orders featured with globalization, security, harmony, and stability. In the era of globalization, due to information communication media, everyone can know and understand important events happened in the world immediately. Thanks for convenient transportation everybody can travel in any place in the world in person. The Earth is everyone's Earth. The world is everyone's world. "For all of the people, on this planet, there is only one right for man living. (Ulrich Beck, Jurgen Habermas, 2000, p202)" Thus, at the era of globalization, everyone should face and care for world peace. Not everyone is aware of the seriousness of world peace issue in the world. Many people fell numb for the preciousness and fragility of world peace. Some people are always seeking for satisfying self interests at the cost of threatening world peace. People with conscience connect self affection with world peace, praying for world peace, and struggling for world peace.

In 2009, the Nobel Peace Prize is awarded the U.S. President Barack Obama, not in recognition of his practical contribution to improving world peace ------ because he has not achieved such a performance, but his attitude to improving world peace in surface. Not considering the embarrassment of the winner and the awarder, from which we can see into the plight of the world peace and the gap between the fruits and the expectations of world peace. It finally shows how strongly the world desires for world peace, just as beggars desire for food.

\section{The ideal of world peace}

From the perspective of human spirit, peace is a special state for human social relations, which is in line with the ideal state required by high humanity and happy life. Before human beings understand the composition, scale, form, and structure of the world, they take world peace as a desired goal. World peace is a beautiful ideal of mankind. Throughout the history, mankind's quest for world peace has never stopped for generations. Peace in the world embodies the lofty ideals of human nature, and is entrusted with the love of humanity. World peace means reasonable and fair world orders, and fair and just international relations. World peace helps all humanity escape from wars, killings, and pains. Only in the sunlight of world peace, mankind can enjoy a happy life. "No world peace, there will be no true human happiness. (Cornelius. F. Murphy, Jr., 2007, p20)"

Throughout the ages, mankind has suffered from wars all the time. The war has stimulated people's pursuit and longing for peace. People in wars pray for peace as they are wounded or dying. The mothers who lost their children in wars are longing for world peace with sadness. War orphans who lost their homes pray for world peace in ruins of wars. The hungry refugees are longing for world peace in the barren wilderness. However, peace is always less than a reliable guarantee. International relations are lack of a perfect and effective credit mechanism. Any cease-fire agreement between belligerents can ensure a lasting peace. And no peace treaty can avoid the outbreak of wars between parties. A puzzling phenomenon appears: at every era of human history, the ideal and the reality of world peace show a large gap. As a result, world history is a history of wars but not a history of peace.

The ideal of mankind would be divided into two kinds: one can be achieved at certain history period. People can live an ideal life in certain aspect after striving. One can not be achieved ever. People can be close to the ideal but never achieve it. In certain field, mankind has already achieved some long- cherished ideals. History proves human beings' capability of achieving ideals. However, the ideal of world peace remains elusive.

\section{Universal peace in the world}

Any nation or state is reluctant to live in chaos and wars. In this sense, all nations and states should be peace-loving. Since ancient times, not any nation or state claims to be the enemy of world peace. History has 
never taken certain nation or state as the opponent of world peace. To destruct world peace is a crime but not a glory.

Although there are kinds of differences between various nations, differences of national cultures do not include peace and anti-peace elements. Not any national culture is against world peace. All national cultures are longing for peace. Under special history conditions, the performance of some extremists and militants does not represent the spirit of whole nation. One of important components of national culture is religion. All religions have the same basic teachings and precepts of peace-loving, advocating for peace. Those ideologies that mislead the nation and the country into wars, including the narrow concept of anti-peace, barbaric ideas, and ignorance, will not be widely approved and supported in world forum.

As an ideal, world peace is the common pursuit and longings for all nations and countries. As a practice, world peace is the common responsibility and obligation of all nations and countries. Only by striving to achieve world peace, each nation and country can get real security. If not committed to world peace, no one nation or country can achieve real security.

\section{The danger for world peace}

The two world wars happened in $20^{\text {th }}$ century repeatedly warn people of how fragile the world peace is. When some special characters driven by evil desires master the destiny of people and nations, or they combine together to harm the public and society, a giant evil power comes into being, which will turn into a devastating damage on world peace.

"Many philosophers have been pondering with an apparent contradiction: almost all religions advocate the peace among people, however, a number of wars start in the name of religions. (J. Orstum Moller, 2003, p256)" In order to survive, everyone needs security. However, some people choose to trample on the peace in order to obtain self interests. If the world achieves a permanent peace, those who produce and promote war machines will completely lose their means of livelihood and wealth opportunity.

While there is truth, good and beauty and love of high-quality ingredients in human nature, human nature also has bad parts. Some people are excited with the wars happened between other countries. In a multi-lateral game, some people build their security interests on others' dangers.

As the degree of globalization is increasing step by step, violence and terrorist activities threaten the world peace more and more. In the era of globalization, because political, economic, and cultural connections between world countries become more frequent, the flow of people, logistics, capital flow, and information flow are more convenient, the destructions and bad results caused by terrorist activities are persuasive and powerful.

Because international race between parties lacks of necessary integrity and coordination, the situation of controlling arms is uncertain. The prospect is still in the dark clouds. Weapons for wars develops from ancient knives, spears, swords, and halberd to modern guns, tanks, aircrafts, missiles, and even nuclear bombs, biological and chemical weapons. The destructive power is growing. This can not be proud of achievements but should be concerned about the condition. The activity that endangers world peace, in the name of safeguarding national security, is still under a legal signboard. The strong firstly has developed and possessed nuclear weapons, biological weapons, chemical weapons, and other mass destructive weapons. They do not intend to abandon their own advantage. The weak wants to develop and possess these kinds of weapons in order to break the asymmetry of military power. The cruelty and the severe consequence of future wars will exceed the record of history. The two world wars occurred in $20^{\text {th }}$ century have already proved how weak the ability of human control the situation and avoid wars. The world situation is likely to continue to deteriorate, again out of control. The human will kill each other in the near future.

\section{The urgency of world peace}

With the coming era of globalization, when people sense that the Earth has become smaller and suddenly see that the globalization problem and the aggravating crisis, they desire for world peace more and more. The world has never demanded for the solidarity of all human beings. Unfortunately, most people do not realize this point. If we recognize the interests of all human beings and take it as the common behavior of evaluating people, we can draw a conclusion on human's common behaviors: sacrifice the long-term interests at expense of short-term interests, and sacrifice the whole interests at the expense of partial interests.

After human has turned into the man from the animal world, following the law of natural selection, and completing the biological evolution, the biggest competitor is not the nature but the human self. Security threat to human society comes from the inside. If the human did not destroy the natural environment at a large scale, the natural environment does not and is not the exterior threat to human society. The invasion from aliens and 
astronauts is only a fiction, without any possibility.

Before the globalization, no matter how serious the war is, it does not cause the destruction of human. As the history comes into the globalization, a critical point is here. Facing the nature, it seems that human is clearer and clearer, and stronger and stronger. Endless advanced technologies carry great and super power, benefiting the human being in many fields. However, once the energy controlled by human exceeds the limit of rationality, the result will be self destruction. "Similar to the dinosaurs, human beings may be ended one day. (Ulrich Beck, Jurgen Habermas, 2000, p202)"

At the critical time, nobody knows some important principal issues. Who and what destroy world peace? Who and what stop the process of world peace? So, vandals continue to their damages and barriers continue to barrier. Therefore, nobody can answer this question: how far is the development process of human society from world peace?

\section{The practice of world peace}

In fact, many individuals, groups and organizations, nations and countries have been working hard for world peace. However, it is necessary to improve the methods, explore new recognitions, and find effective ways, in order to achieve significant effects. It is meaningless to hope the wise to program world peace process for human being. Maybe nobody knows how to realize world peace. But, everyone has the responsibility and obligation to contribute to the solution of the problem, presenting self answers. "Ultimately, the future of our planet is in the hands of everyone. (Mel Gurtov, 2000, p347)"

On one hand, we must enhance human recognition. From the knowledge, morals, laws, education and other many aspects, we should seek for, identify, follow, and obey the principles and morals in human society, such as equality, reason, respect, trust, tolerance, moderation, balance, etc. Take them as the cornerstone of peace and build a harmonious relation among people. Build a recognition system including following contents: a standard measuring world peace, the force destroying world peace, the power maintaining world peace, factors hurting world peace, conditions for realizing world peace, ways for world peace, and measures for promoting world peace. For all group consciousness and ideas that betray the will of world peace and the spirit of world peace, such as hegemony, terrorism, hate doctrine, and narrow nationalism, we must research it objectively and criticize it rationally. As for the harmful information conveyed by abnormal cultural phenomenon, betraying the will of peace and the spirit of peace, such as violence information, evil information, ignorance information, and barbaric information, we must take proper means to restrict them.

On the other hand, we must improve human behavior. Search and find the defects in national and international political system and laws. Learn from and take reference from the wonderful design ideas as human beings changing the nature. Design sorts of social system, similar to technological design, product design, construction design, and engineering design. Establish a mechanism to solve kinds of social conflicts and avoid the burst of social conflicts. Depress and prevent any kind of social violence. Eliminate wars and terrorist activities, just as the eradication of smallpox. Create a new world without violence, wars, or terrorism. Accordingly, the international community has many specific tasks, such as constituting the code of world peace, developing the theories of world peace, founding the world peace colleges and institutions, forming all kinds of world peace organizations, setting up world peace funds, signing world peace charters and declarations, and so on.

"The war between human beings is not the destiny. (Sidey Hook, 2006, p178)" Human can make many things come true. Build taller skyscrapers. Fly toward the space farer and farer. Wish the world peace is not a dream. For world peace, we must continue to desire and explore.

\section{References}

Ulrich Beck, Jurgen Habermas. Translated by Wang, Xuedong \& Chai, Fangguo. (2000). Globalization and Politics. Beijing: Central Compilation \& Translation Press. p202.

Cornelius. F. Murphy, Jr. Translated by Wang, Qiliang., Wang, Yahong \& Wang, Wen. (2007). Theories of World Governance: A Study in the History of Ideas. Beijing: World Affairs Press. p20.

J. Orstum Moller. Translated by Jia, Zongyi. (2003). The End of Internationalism or World Governance. Beijing: Xinhua Press. p256.

Mel Gurtov. Translated by Jia, Zongyi. (2000). Global Politics in the Human Interest. Beijing: Xinhua Press. p347.

Sidey Hook. Translated by Wang, Qingbin. (2006). The Hero in History. Shanghai: Shanghai People's Publishing House. p178. 